\title{
Assessment of Depression, Anxiety, and Sleep Disturbance in COVID-19 Patients at Tertiary Care Center of North India
}

\author{
Ramakant Yadav ${ }^{1}$ Prashant Yadav ${ }^{2}$ Sushil Shukla Kumar ${ }^{3}$ Raj Kumar ${ }^{4}$ \\ ${ }^{1}$ Department of Neurology, UP University of Medical Sciences, \\ Saifai, Etawah, Uttar Pradesh, India \\ ${ }^{2}$ Department of Respiratory Medicine, UP University of Medical \\ Sciences, Saifai, Etawah, Uttar Pradesh, India \\ ${ }^{3}$ Department of Community Medicine, UP University of Medical \\ Sciences, Saifai, Etawah, Uttar Pradesh, India \\ ${ }^{4}$ Department of Neurosurgery, UP University of Medical Sciences, \\ Saifai, Etawah, Uttar Pradesh, India \\ Address for correspondence Ramakant Yadav, DM, Department \\ of Neurology, UP University of Medical Sciences, Saifai, Etawah \\ 206130, Uttar Pradesh, India (e-mail: rkyadav_2003@yahoo.com).
}

J Neurosci Rural Pract 2021;12:316-322.

\begin{abstract}
Background and Objective The novel Coronavirus pandemic surfaced in Wuhan, China in December 2019 and spread rapidly across the globe. In recent available literature, most of the studies were done to estimate the burden of psychiatric problems among general population due to this pandemic, Therefore, this study was planned to assess depression, anxiety, and sleep disturbance among Coronavirus disease-2019 (COVID-19) patients.

Materials and Methods A hospital-based, cross-sectional study was done from June 2020 to August 2020 among 100 COVID-19 patients who were admitted and fulfilled the inclusion criteria. Assessment of depression, anxiety, and sleep disturbance were done by patient health questionnaire-9 (PHQ-9) scale, generalized anxiety disorder-7 (GAD-7) scale and Pittsburg sleep quality index (PSQI), respectively.

Results In this study, $73 \%$ were males and $27 \%$ were females. The mean age of the patients in present study was $42.90 \pm 16.33$ years. This study reveals that depression was in $27 \%$, anxiety in $67 \%$, and sleep disturbance in $62 \%$ of patients. Depression and anxiety were found significantly associated with presence of comorbidity and severity of illness $(p<00.05)$. The association of sleep disturbance with severity of illness was also found statistically significant $(p<0.05)$.

Conclusion The risk of psychological stress is high in COVID-19 patients. The psy-

Keywords

- COVID-19

- depression

- anxiety

- sleep disturbance chological problems among COVID-19 patients are commonly related to the consequences of disease, and severity and contagiousness of the disease. Therefore, in this present pandemic situation, it is more important to identify these psychological problems among COVID-19 patients, so that better care and timely interventions can be done with respect to psychological issues.
\end{abstract}

published online January 29, 2021
DOI https://doi.org/

10.1055/s-0040-1722811 ISSN 0976-3147. (c) 2021. Association for Helping Neurosurgical Sick People. This is an open access article published by Thieme under the terms of the Creative Commons Attribution-NonDerivative-NonCommercial-License, permitting copying and reproduction so long as the original work is given appropriate credit. Contents may not be used for commercial purposes, or adapted, remixed, transformed or built upon. (https://creativecommons.org/licenses/by-nc-nd/4.0/). Thieme Medical and Scientific Publishers Pvt. Ltd. A-12, 2nd Floor, Sector 2, Noida-201301 UP, India 


\section{Introduction}

Central nervous system (CNS) is infected by variety of viruses, and it can be manifested as neuropsychiatric syndromes of cognitive and behavioral impairment. ${ }^{1-3}$ Coronaviruses are single-stranded RNA viruses, and there are many strains of Coronavirus which have been affected humans and manifested as mild upper respiratory tract infections in healthy individuals. ${ }^{4,5}$ These Coronaviruses also have been found in the cerebrospinal fluid (CSF) of the patients who presented with seizures, encephalitis, and encephalomyelitis. ${ }^{6}$

The severe acute respiratory syndrome (SARS) and the Middle East respiratory syndrome (MERS) outbreaks were caused by novel strains of Coronavirus in 2002 and 2012, respectively. ${ }^{5}$ The novel Coronavirus pandemic, which broke out in Wuhan, China, in December 2019 and spread rapidly across the globe, was caused by severe acute respiratory syndrome Coronavirus-2 (SARS-CoV-2). Both SARS-CoV-2 infected patients and general population might be at increased risk of psychological problems due to the consequences of pandemic such as physical isolation and stressful environment. ${ }^{7-9}$

These COVID-19 patients are more vulnerable to develop neuropsychiatric syndromes because of the stigma associated with disease and concern about the outcome of this infection. ${ }^{10,11}$ In recent studies, it was found that psychological problems affected the general well-being of SARS-CoV-2 infected patients as well as the general public significantly. ${ }^{12}$

Sleep is very important for good quality of life, and in previous studies, it was found that sleep disturbances was an important risk factor for suicidal tendencies, and sleep abnormalities were also associated with anxiety and depression. ${ }^{13}$

There are multiple causes of psychiatric manifestation of Coronavirus infection; they might be immunological response toward infection, cerebrovascular disease and level of physiological impairment and psychological effect of this contagious viral illness. ${ }^{14}$

Psychological problems are gaining attention in this present situation of pandemic, and there is very little information on increase in psychological problems in this present scenario. ${ }^{15}$

There is already evidence of neuropsychiatric manifestations among COVID-19 patients, so physicians should be alert to evaluate mental disorders in these patients, so that timely intervention can be done. Therefore, this study was planned to assess the anxiety, sleep disturbance, and depression among COVID-19 patients.

\section{Materials and Methods}

A hospital-based, cross-sectional study was done from June 2020 to August 2020 among 100 COVID-19 patients who were admitted, and fulfilled the study protocol, in the indoor of a COVID-19 hospital of a tertiary care center in rural Uttar Pradesh, north India. This institution is run by state government, and patients were referred from nearby districts.
These patients were classified into mild, moderate, and severe categories of COVID-19 illness, depending upon severity of symptoms like those patients who had fever, dry cough, myalgia and other nonspecific symptoms were categorized as mild illness, while those patients had above symptoms along with dyspnea on exertion or tachypnoea (respiratory rate $[R R]>24 /$ minute) and saturation of peripheral oxygen $\left(\mathrm{SpO}_{2}\right) 90$ to $94 \%$ on room air were categorized as moderate illness; patients having any of the above signs and symptoms with SPO2 less than $90 \%$ on room air or RR $>30 /$ minutes were categorized into "severe illness" category.

\section{Sample Size}

This study was done from June 2020 to August 2020; 100 COVID-19 patients among those admitted and who fulfilled the inclusion criteria were taken for study.

\section{Inclusion and Exclusion Criteria}

Age 18 years or more who were admitted with positive reverse transcriptase-polymerase chain reaction (RT-PCR) test for SARS-CoV-2 were included. Those who refused to provide consent to participate in the study, critically ill $\left(\mathrm{SpO}_{2}<90 \%\right.$ with shock or altered sensorium $)$ and requiring ventilatory support for management, hemodynamically unstable, with other known mental health disorders, and/or those who were taking such drugs which can affect the mind, emotions, and behavior, were excluded from the study.

Data were collected from patients according to a predesigned and pretested proforma gathering sociodemographic characteristics, comorbidity, and disease severity. Assessment of depression, anxiety, and sleep disturbance were done by patient health questionnaire-9 (PHQ-9) scale, generalized anxiety disorder-7 (GAD-7), scale and Pittsburg sleep quality Index (PSQI), respectively.

PHQ-9 scale: This scale is a 9-question instrument used for assessment of presence and severity of depression. The range of PHQ-9 score is 0 to 27, as response of each of the 9 question will be scored from 0 (not at all) to 3 (nearly every day). If score is 0 to 4 , then there is no depression; if score is 5 to 9 , then there is mild depression; if score is 10 to 14 , then there is moderate depression; if score is 15 to 19 , then there is moderately severe depression; if score is 20 to 27 , then there is severe depression. ${ }^{16}$

GAD-7 scale: The range of GAD-7 score is 0 to 21 , as response of each question is scored from 0 (not at all) to 3 (nearly every day). If score is 0 to 5 , then there is no anxiety; if score is 6 to 10 , then there is mild anxiety; if score is 10 to 15 , then there is moderate anxiety; if score is 16 to 21 , then it is labeled as severe anxiety. ${ }^{17}$

Assessment of sleep disturbance was done by PSQI. This index is used to assess sleep quality in the previous month. It has 19 self-rated questions which are divided into seven components: sleep quality, sleep duration, sleep latency, habitual sleep efficiency, sleep disturbance, use of sleeping medicine, and daytime dysfunction. Response to each of the components can be scored from 0 (no difficulty) to 3 (severe difficulty), so the range of total score (global score) of these 
seven components can be 0 to 21 . In this study, score $>7$ was taken for determination of sleep disturbance. ${ }^{18}$

\section{Statistical Analysis}

The data were analyzed using SPSS software, version 25 (IBM Corp., Chicago, USA). Chi-square test was used to establish the relationship among different variables, and $p<0.05$ was considered statistically significant.

\section{Results and Observations}

The mean age of the patients in the study was $42.90 \pm$ 16.33 years, with a range from 18 to 70 years. There were $28 \%$ of patients found in the age group of 18 to 29 years, which was the most common age group. Out of 100 patients, there were $73 \%$ males and $27 \%$ females. Majority of the patients in study were literate (85\%) and above the poverty line (93\%). There were $24 \%$ smokers, $14 \%$ alcoholics, and $9 \%$ both smokers and alcoholics, and among alcoholics, all were occasionally alcoholic none of them was addicted to alcohol .In this study, we found diabetes in $13 \%$, hypertension in $13 \%$, chronic obstructive pulmonary disease (COPD) in $4 \%$, and asthma in 3\% of COVID-19 patients . There were $61 \%$ mild cases, $19 \%$ moderate cases, and $15 \%$ severe cases in the study (- Table 1).

In this study depression was found among $27 \%$ COVID-19 patients. Among depression, mild depression 21\%, moderate 4\%, moderately severe was $2 \%$ (-Fig. 1) In this study, mean PHQ-9 score was 3.54 \pm 2.93 , and when PHQ-9 score of depressive patients was compared with their severity of illness, it was found to be statistically significant $(p<0.05)$.
Table 1 Demographic profile of COVID-19 patients

\begin{tabular}{|c|c|c|c|}
\hline S. no. & $\begin{array}{l}\text { Variable } \\
\text { name }\end{array}$ & Subgroups & $\begin{array}{l}\text { Total } \\
n=100(\%)\end{array}$ \\
\hline \multirow[t]{8}{*}{1} & \multirow{8}{*}{$\begin{array}{l}\text { Age } \\
\text { (years) }\end{array}$} & $18-29$ & $28(28.0)$ \\
\hline & & 30-39 & $19(19.0)$ \\
\hline & & $40-49$ & $16(16.0)$ \\
\hline & & 50-59 & $18(18.0)$ \\
\hline & & $60-69$ & $12(12.0)$ \\
\hline & & $70-79$ & $05(05.0)$ \\
\hline & & $\geq 80$ & $02(02.0)$ \\
\hline & & Mean \pm SD & $42.90 \pm 16.33$ \\
\hline \multirow[t]{2}{*}{2} & \multirow[t]{2}{*}{ Gender } & Male & $73(73.0)$ \\
\hline & & Female & $27(27.0)$ \\
\hline \multirow[t]{2}{*}{3} & \multirow{2}{*}{$\begin{array}{l}\text { Socioeconomic } \\
\text { status }\end{array}$} & APL & $93(93.0)$ \\
\hline & & BPL & $07(7.0)$ \\
\hline \multirow[t]{3}{*}{4} & \multirow{3}{*}{$\begin{array}{l}\text { Behavioral } \\
\text { factors }\end{array}$} & Smoker & $24(24.0)$ \\
\hline & & Alcoholic & $14(14.0)$ \\
\hline & & Smoker and alcoholic & $09(9.0)$ \\
\hline \multirow[t]{4}{*}{5} & \multirow{4}{*}{$\begin{array}{l}\text { Presence of } \\
\text { comorbidity }\end{array}$} & Diabetes & $13(13.0)$ \\
\hline & & Hypertension & $13(13.0)$ \\
\hline & & COPD & $04(4.0)$ \\
\hline & & Asthma & $03(3.0)$ \\
\hline \multirow[t]{3}{*}{6} & \multirow{3}{*}{$\begin{array}{l}\text { Severity of } \\
\text { illness }\end{array}$} & Mild & $66(66.0)$ \\
\hline & & Moderate & $19(19.0)$ \\
\hline & & Severe & $15(15.0)$ \\
\hline
\end{tabular}

Abbreviations: APL, above poverty line; BPL, below poverty line; COPD, chronic obstructive pulmonary disease; SD, standard deviation.

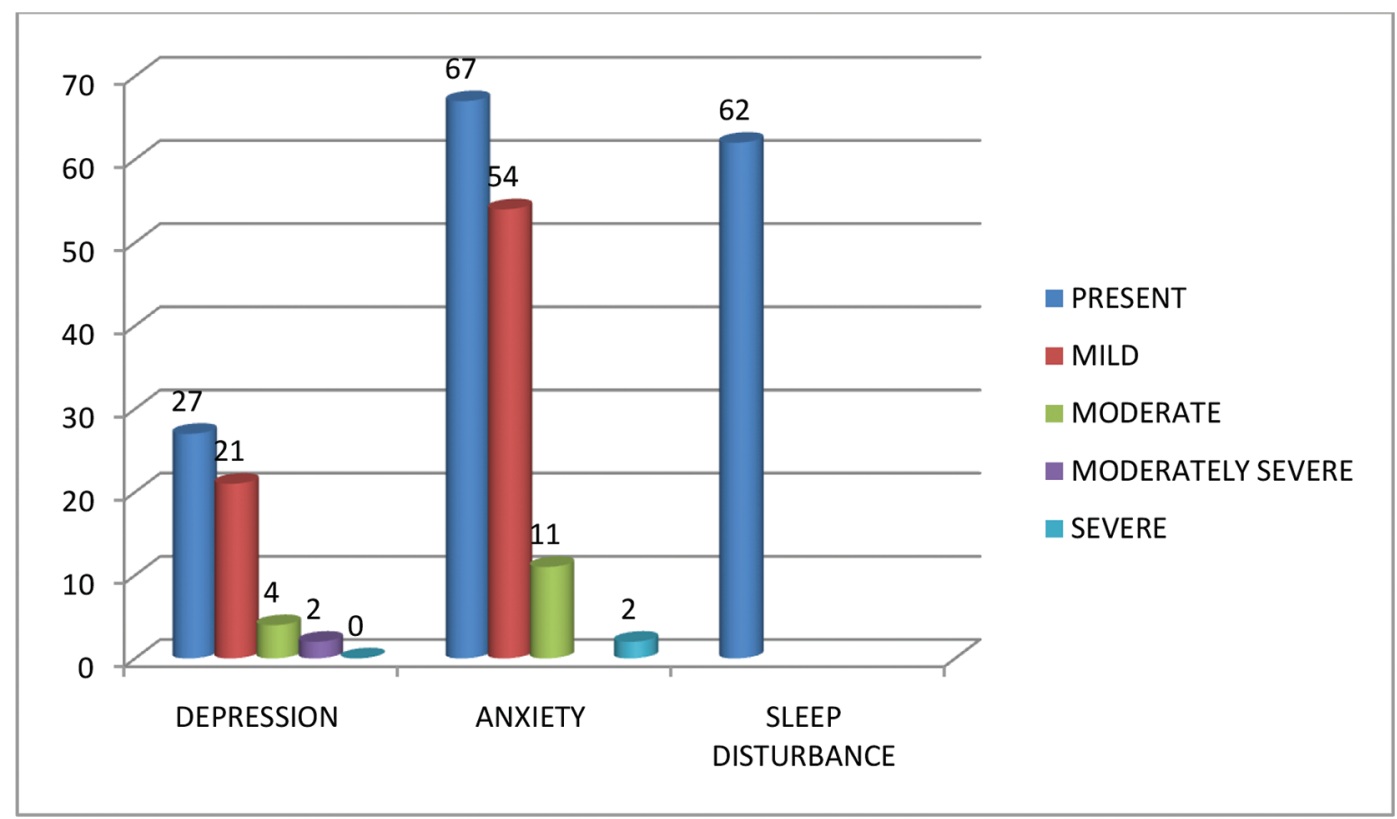

Fig. 1 Distribution of depression, anxiety, and sleep disturbance in COVID-19 patients 
- Table 2 depicts the various associations of depression with age group, gender, socioeconomic status, behavioral factors, presence of comorbidity, and severity of illness. We found the association to be statistically significant in age group, comorbidity, and severity of illness $(p<0.05)$, while it was not statistically significant with regard to gender, behavioral factors, and socioeconomic status.

In this study, anxiety was found in 67\% COVID-19 patients, mild anxiety in 54\%, moderate in $11 \%$, and severe anxiety in $2 \%$ ( - Fig. 1). Mean GAD-7 score was $5.81 \pm 3.70$, and when GAD-7 score of anxiety was compared with severity of illness, it was found to be statistically significant $(p<0.05)$.

- Table 3 depicts the various associations of anxiety with age group, gender, socioeconomic status, behavioral factors, presence of comorbidity, and severity of illness. We found this association statistically significant in the presence of comorbidity and severity of illness $(p<0.05)$, while it was not statistically significant with regard to age group, gender, behavioral factors, and socioeconomic status.

In this study, sleep quality disturbance was found in $62 \%$ patients and mean PSQI score was $8.84 \pm 3.28$; when PSQI score was compared with severity of illness, it was found to be statistically significant $(p<0.05)$.

- Table 4 depicts the various association of sleep quality disturbance with age group, gender, socioeconomic status, behavioral factors, presence of comorbidity, and severity of illness. We found this association statistically significant in severity of illness $(p<0.05)$, while it was not statistically significant with regard to age group, gender, behavioral factors, socioeconomic status, and presence of comorbidity.

\section{Discussion}

The quality of life of people worldwide has been affected by this COVID-19 outbreak, and the impact of this disease on mental health can be quite complex. ${ }^{16}$ An association between epidemic and mental disorder has been found from the studies during the outbreak of SARS and MERS outbreak in the past. ${ }^{19,20}$ Similarly, in previous studies, higher risk of psychiatric impairment was identified in a significant proportion of patients of H1N1.21,22 In this study, depression (27\%), anxiety (67\%), and sleep quality disturbance (62\%) were found in COVID-19 patients. Wang et al found in their study that $53.8 \%$ of individuals among general population experienced severe psychological effects of this outbreak. ${ }^{23}$

In this study, depression was found in $27 \%$ patients and males experienced more depression than females (21\% vs. 06\%). Depression was associated with presence of comorbidity and severity of illness, and this association was

Table 2 Association of depression in COVID-19 patients

\begin{tabular}{|c|c|c|c|c|}
\hline S. no. & Variable name & Subgroups & Depression (\%) & $\begin{array}{l}\text { Chi-square } \\
\text { (p-value) }\end{array}$ \\
\hline \multirow[t]{8}{*}{1} & \multirow{8}{*}{$\begin{array}{l}\text { Age } \\
\text { (years) }\end{array}$} & $18-29$ & $04(14.3)$ & \multirow[t]{8}{*}{$15.19(p<0.05)$} \\
\hline & & $30-39$ & $05(26.3)$ & \\
\hline & & $40-49$ & $03(18.8)$ & \\
\hline & & $50-59$ & $09(50.0)$ & \\
\hline & & $60-69$ & $04(33.3)$ & \\
\hline & & $70-79$ & 00.00 & \\
\hline & & $\geq 80$ & $02(100.0)$ & \\
\hline & & Total & $27(27.0)$ & \\
\hline \multirow[t]{2}{*}{2} & \multirow[t]{2}{*}{ Gender } & Male & $21(28.8)$ & \multirow[t]{2}{*}{$0.43(0.51)$} \\
\hline & & Female & $06(22.2)$ & \\
\hline \multirow[t]{2}{*}{3} & \multirow{2}{*}{$\begin{array}{l}\text { Socioeconomic } \\
\text { status }\end{array}$} & APL & $25(26.9)$ & \multirow[t]{2}{*}{$0.009(0.92)$} \\
\hline & & $\mathrm{BPL}$ & $02(28.6)$ & \\
\hline \multirow[t]{3}{*}{4} & \multirow[t]{3}{*}{ Behavioral factors } & Smoker & $07(29.2)$ & \multirow[t]{3}{*}{$2.43(0.48)$} \\
\hline & & Alcoholic & $06(42.9)$ & \\
\hline & & Smoker and alcoholic & $02(22.2)$ & \\
\hline \multirow[t]{4}{*}{5} & \multirow[t]{4}{*}{ Presence of comorbidity } & Diabetes & $08(61.5)$ & \multirow[t]{4}{*}{$9.81(p<0.05)^{\mathrm{a}}$} \\
\hline & & Hypertension & $03(23.1)$ & \\
\hline & & COPD & $01(25.0)$ & \\
\hline & & Asthma & $00(0.0)$ & \\
\hline \multirow[t]{3}{*}{6} & \multirow[t]{3}{*}{ Severity of illness } & Mild & $12(18.2)$ & \multirow[t]{3}{*}{$8.82(p<0.05)^{\mathrm{a}}$} \\
\hline & & Moderate & $07(36.8)$ & \\
\hline & & Severe & $08(53.3)$ & \\
\hline
\end{tabular}

Abbreviations: APL, above poverty line; BPL, below poverty line; COPD, chronic obstructive pulmonary disease.

aStatistically significant. 
Table 3 Association of anxiety in COVID-19 patients

\begin{tabular}{|c|c|c|c|c|}
\hline S no. & Variable name & Subgroups & Anxiety (\%) & Chi-square value ( $p$-value) \\
\hline \multirow[t]{8}{*}{1} & \multirow{8}{*}{$\begin{array}{l}\text { Age } \\
\text { (years) }\end{array}$} & $18-29$ & $20(71.3)$ & \multirow[t]{7}{*}{$21.41(0.30)$} \\
\hline & & $30-39$ & $14(26.3)$ & \\
\hline & & $40-49$ & $07(44.7)$ & \\
\hline & & $50-59$ & $14(77.8)$ & \\
\hline & & $60-69$ & $07(59.3)$ & \\
\hline & & $70-79$ & $03(60.0)$ & \\
\hline & & $\geq 80$ & $02(100.0)$ & \\
\hline & & Total & $67(67.0)$ & \\
\hline \multirow[t]{2}{*}{2} & \multirow[t]{2}{*}{ Gender } & Male & $47(74.4)$ & \multirow[t]{2}{*}{$0.93(0.18)$} \\
\hline & & Female & $20(61.3)$ & \\
\hline \multirow[t]{2}{*}{3} & \multirow{2}{*}{$\begin{array}{l}\text { Socioeconomic } \\
\text { status }\end{array}$} & APL & $62(76.4)$ & \multirow[t]{2}{*}{$1.45(0.70)$} \\
\hline & & BPL & $05(71.4)$ & \\
\hline \multirow[t]{3}{*}{4} & \multirow[t]{3}{*}{ Behavioral factors } & Smoker & $14(59.3)$ & \multirow[t]{3}{*}{$10.22(0.33)$} \\
\hline & & Alcoholic & $07(50.0)$ & \\
\hline & & Smoker and alcoholic & 08 (89.9) & \\
\hline \multirow[t]{4}{*}{5} & \multirow[t]{4}{*}{ Presence of comorbidity } & Diabetes & $11(84.6)$ & \multirow[t]{4}{*}{$24.16(p<0.05)^{*}$} \\
\hline & & Hypertension & $10(76.9)$ & \\
\hline & & COPD & $03(75.0)$ & \\
\hline & & Asthma & $01(33.7)$ & \\
\hline \multirow[t]{3}{*}{6} & \multirow[t]{3}{*}{ Severity of illness } & Mild & 39 (59.9) & \multirow[t]{3}{*}{$27.41(<0.05)^{\mathrm{a}}$} \\
\hline & & Moderate & $14(73.7)$ & \\
\hline & & Severe & $14(93.3)$ & \\
\hline
\end{tabular}

Abbreviations: APL, above poverty line; BPL, below poverty line; COPD, chronic obstructive pulmonary disease.

aStatistically significant.

statistically significant $(p<0.05)$. In other studies, prevalence of depression was found to be 8.3 to $48.3 \%$ in China, ${ }^{24,25} 25 \%$ in India, and 15.4 to $17 \%$ in Italy among general population. ${ }^{26,27}$

In this study, we found anxiety in $67 \%$ cases; among them, $47 \%$ were male and $20 \%$ were female. We found $54 \%$ mild, $11 \%$ moderate, and $2 \%$ severe anxiety cases in the study. The association of anxiety with severity of illness $(p<0.05)$ and presence of comorbidity ( $p<0.05$ ) were statistically significant. Xiao et al found high levels of anxiety and stress in their study done on medical staff in China. ${ }^{28}$

Anxiety was found as predominated manifestation of emotion in the study done by Lima et al. ${ }^{29}$ The prevalence of anxiety was reported in 2 to $37 \%$ of general Chinese population; $24,26,30,31$ in India, prevalence of anxiety was reported to be approximately $28 \%{ }^{26,30}$

In this study, sleep quality disturbance was found in $62 \%$ cases; among them, $44 \%$ male and 18 were female. The association of sleep disturbance with severity of illness was also statistically significant $(p<0.05)$; however, in recent studies, the prevalence of insomnia reported in China ranged from 18.2 to $23.2 \% .^{24,31}$

Qiu et al conducted a study in Chinese population and found $34.43 \%$ were experiencing psychological distress. ${ }^{32}$ Bo et al included an online assessment of attitudes toward mental health services and a screener for posttraumatic stress disorder (PTSD) symptoms in stable COVID-19 patients $(n=714)$ in Wuhan, China. They found approximately half of these subjects felt that available psychological interventions were helpful (49.8\%). The prevalence of psychological distress among COVID-19 patients was understandably much higher. ${ }^{33}$ It has been found that physical distancing, severity of disease, unpredictability, and misinformation, can cause anxiety and fear. ${ }^{34}$ In recent study, it has been seen that those patients who were kept in isolation and quarantine suffered higher level of stress and anxiety. ${ }^{7}$

\section{Conclusion}

Psychological stress is one of the important aspects in the management of COVID-19 patients. In this study, we found that depression was $27 \%$, anxiety was $67 \%$, and sleep disturbance was 63\% among admitted COVID-19 patients. Depression was statistically significantly associated with age group, presence of comorbidity, and severity of disease. Anxiety was statistically significantly associated with presence of comorbidity and severity of disease, and sleep disturbance was statistically significantly associated with severity of illness.

The psychological problems among COVID-19 patients commonly related to consequences of disease, severity of illness, and contagiousness of the disease. Therefore, in this 
Table 4 Association of sleep quality disturbance in COVID-19 patients

\begin{tabular}{|c|c|c|c|c|}
\hline S. no. & Variable name & Subgroups & Sleep quality disturbance (\%) & $\begin{array}{l}Z \text { value, } \\
p \text {-value }\end{array}$ \\
\hline \multirow[t]{8}{*}{1.} & \multirow{8}{*}{$\begin{array}{l}\text { Age } \\
\text { (years) }\end{array}$} & $18-29$ & $14(50)$ & \multirow[t]{8}{*}{$0.93(0.16)$} \\
\hline & & $30-39$ & $14(73.7)$ & \\
\hline & & $40-49$ & $07(43.7)$ & \\
\hline & & $50-59$ & $14(77.80)$ & \\
\hline & & $60-69$ & $09(75.0)$ & \\
\hline & & $70-79$ & $02(40.0)$ & \\
\hline & & $\geq 80$ & $02(100)$ & \\
\hline & & Total & $62(62.0)$ & \\
\hline \multirow[t]{2}{*}{2.} & \multirow[t]{2}{*}{ Gender } & Male & $44(60.30)$ & \multirow[t]{2}{*}{$0.86(0.35)$} \\
\hline & & Female & $18(66.66)$ & \\
\hline \multirow[t]{2}{*}{3.} & \multirow{2}{*}{$\begin{array}{l}\text { Socioeconomic } \\
\text { Status }\end{array}$} & APL & $57(61.20)$ & \multirow[t]{2}{*}{$0.23(0.63)$} \\
\hline & & $\mathrm{BPL}$ & $05(71.40)$ & \\
\hline \multirow[t]{3}{*}{4.} & \multirow[t]{3}{*}{ Behavioral factors } & Smoker & $16(66.66)$ & \multirow[t]{3}{*}{$0.41(0.33)$} \\
\hline & & Alcoholic & $08(57.10)$ & \\
\hline & & Smoker and alcoholic & $06(66.67)$ & \\
\hline \multirow[t]{4}{*}{5.} & \multirow[t]{4}{*}{ Presence of comorbidity } & Diabetes & $11(84.60)$ & \multirow[t]{4}{*}{$4.55(0.34)$} \\
\hline & & Hypertension & $9(69.20)$ & \\
\hline & & COPD & $02(50)$ & \\
\hline & & Asthma & $1(33.70)$ & \\
\hline \multirow[t]{3}{*}{6.} & \multirow[t]{3}{*}{ Severity of illness } & Mild & $31(46.96)$ & \multirow[t]{3}{*}{$18.43(p<0.05)^{\mathrm{a}}$} \\
\hline & & Moderate & $16(84.20)$ & \\
\hline & & Severe & $15(100)$ & \\
\hline
\end{tabular}

Abbreviations: APL, above poverty line; BPL, below poverty line; COPD, chronic obstructive pulmonary disease.

a Statistically significant.

present pandemic situation, it is more important to identify these psychological problems among COVID-19 patients, so that better care and timely interventions can be arranged with respect to psychological issues.

\section{Limitations}

This is a single-center, cross-sectional study which limits the generalizability of our findings. Therefore, further research should be done regarding evaluation of psychological problems and their interventions in COVID-19 patients.

\section{Ethical Approval}

Informed written consent was obtained from each participant at the time of their enrollment in the study. 'Ethical clearance was taken from the Ethical Committee of the University before the commencement of the study.

\section{Funding}

None.

\section{Conflict of Interest}

None declared.

\section{References}

1 Arciniegas DB, Anderson CA. Viral encephalitis: neuropsychiatric and neurobehavioral aspects. Curr Psychiatry Rep 2004;6(5):372-379

2 Dubé B, Benton T, Cruess DG, Evans DL. Neuropsychiatric manifestations of HIV infection and AIDS. J Psychiatry Neurosci 2005;30(4):237-246

3 Hinkin $\mathrm{CH}$, Castellon SA, Atkinson JH, Goodkin K. Neuropsychiatric aspects of HIV infection among older adults. J Clin Epidemiol 2001;54(Suppl 1):S44-S52

4 Lu R, Zhao X, Li J, et al. Genomic characterisation and epidemiology of 2019 novel coronavirus: implications for virus origins and receptor binding. Lancet 2020;395(10224):565-574

5 Desforges M, Le Coupanec A, Dubeau P, et al. Human coronaviruses and other respiratory viruses: underestimated opportunistic pathogens of the central nervous system? Viruses 2019;12(1):14

6 Bohmwald K, Gálvez NMS, Ríos M, Kalergis AM. Neurologic alterations due to respiratory virus infections. Front Cell Neurosci 2018;12:386

7 Brooks SK, Webster RK, Smith LE, et al. The psychological impact of quarantine and how to reduce it: rapid review of the evidence. Lancet 2020;395(10227):912-920

8 Asmundson GJ, Taylor S. Coronaphobia: fear and the 2019-nCoV outbreak. J Anxiety Disord 2020;70:102196

9 Greenberg N, Docherty M, Gnanapragasam S, Wessely S. Managing mental health challenges faced by healthcare workers during covid-19 pandemic. BMJ 2020;368:m1211 
10 Xiang Y-T, Yang Y, Li W, et al. Timely mental health care for the 2019 novel coronavirus outbreak is urgently needed. Lancet Psychiatry 2020;7(3):228-229

11 Siu JY. The SARS-associated stigma of SARS victims in the post-SARS era of Hong Kong. Qual Health Res 2008;18(6):729-738

12 Kang L, Li Y, Hu S, et al. The mental health of medical workers in Wuhan, China dealing with the 2019 novel coronavirus. Lancet Psychiatry 2020;7(3):e14

13 Sher L. COVID-19, anxiety, sleep disturbances and suicide. Sleep Med 2020;70:124

14 Rabiee A, Nikayin S, Hashem MD, et al. Depressive symptoms after critical illness: a systematic review and meta-analysis. Crit Care Med 2016;44(9):1744-1753

15 Lakhan R, Agrawal A, Sharma M. Prevalence of Depression, Anxiety, and Stress during COVID-19 Pandemic. J Neurosci Rural Pract 2020;11(4):519-525

16 Kroenke K, Spitzer RL, Williams JB. The PHQ-9: validity of a brief depression severity measure. J Gen Intern Med 2001;16(9):606-613

17 Spitzer RL, Kroenke K, Williams JBW, Löwe B. A brief measure for assessing generalized anxiety disorder: the GAD-7. Arch Intern Med 2006;166(10):1092-1097

18 Buysse DJ, Reynolds CF III, Monk TH, Berman SR, Kupfer DJ. The Pittsburgh Sleep Quality Index: a new instrument for psychiatric practice and research. Psychiatry Res 1989;28(2):193-213

19 McAlonan GM, Lee AM, Cheung V, et al. Immediate and sustained psychological impact of an emerging infectious disease outbreak on health care workers. Can J Psychiatry 2007;52(4):241-247

20 Tucci V, Moukaddam N, Meadows J, Shah S, Galwankar SC, Kapur GB. The forgotten plague: psychiatric manifestations of Ebola, Zika, and emerging infectious diseases. J Glob Infect Dis 2017;9(4):151-156

21 Luyt CE, Combes A, Becquemin MH, et al; REVA Study Group. Long-term outcomes of pandemic 2009 influenza A(H1N1)associated severe ARDS. Chest 2012;142(3):583-592

22 Andersson NW, Goodwin RD, Okkels N, et al. Depression and the risk of severe infections: prospective analyses on a nationwide representative sample. Int J Epidemiol 2016;45(1):131-139

23 Wang C, Pan R, Wan X, et al. Immediate psychological responses and associated factors during the initial stage of the 2019 coronavirus disease (COVID-19) epidemic among the general population in China. Int J Environ Res Public Health 2020;17(5):1729

24 Huang Y, Zhao N. Generalized anxiety disorder, depressive symptoms and sleep quality during COVID-19 outbreak in China: a web-based cross-sectional survey. Psychiatry Res 2020;288:112954

25 Gao J, Zheng P, Jia Y, et al. Mental health problems and social media exposure during COVID-19 outbreak. PLoS One 2020;15(4):e0231924

26 Verma S, Mishra A. Depression, anxiety, and stress and socio-demographic correlates among general Indian public during COVID-19. Int J Soc Psychiatry 2020;66(8):756-762

27 Ozamiz-Etxebarria N, Dosil-Santamaria M, Picaza-Gorrochategui M, Idoiaga-Mondragon N. Stress, anxiety, and depression levels in the initial stage of the COVID-19 outbreak in a population sample in the northern Spain. Cad Saude Publica 2020;36(4):e00054020

28 Xiao H, Zhang Y, Kong D, Li S, Yang N. The effects of social support on sleep quality of medical staff treating patients with coronavirus disease 2019 (COVID-19) in January and February 2020 in China. Med Sci Monit 2020;26:e923549

29 Lima CKT, Carvalho PMM, Lima IAAS, et al. The emotional impact of Coronavirus 2019-nCoV (new Coronavirus disease) Psychiatry Res 2020;287:112915

30 Roy D, Tripathy S, Kar SK, Sharma N, Verma SK, Kaushal V. Study of knowledge, attitude, anxiety \& perceived mental healthcare need in Indian population during COVID-19 pandemic. Asian J Psychiatr 2020;51:102083

31 Zhou SJ, Wang LL, Yang R, et al. Sleep problems among Chinese adolescents and young adults during the coronavirus-2019 pandemic. Sleep Med 2020;74:39-47

32 Qiu J, Shen B, Zhao M, Wang Z, Xie B, Xu Y. A nationwide survey of psychological distress among Chinese people in the COVID-19 epidemic: implications and policy recommendations. Gen Psychiatr 2020;33(2):e100213

33 Bo HX, Li W, Yang Y, et al. Posttraumatic stress symptoms and attitude toward crisis mental health services among clinically stable patients with COVID-19 in China. Psychol Med 2020 (e-pub ahead of print). Doi: 10.1017/S0033291720000999

34 Li W, Yang Y, Liu ZH, et al. Progression of mental health services during the COVID-19 outbreak in China. Int J Biol Sci 2020;16(10):1732-1738 